\title{
Comparative Study of the Antimicrobial Efficacy of Chlorhexidine Gel, Chlorhexidine Solution and Sodium Hypochlorite as Endodontic Irrigants
}

\author{
Caio C. R. FERRAZ \\ Brenda P. F. A. GOMES \\ Alexandre A. ZAIA \\ Fabrício B. TEIXEIRA \\ Francisco J. SOUZA-FILHO
}

Department of Endodontics, School of Dentistry of Piracicaba, University of Campinas, Piracicaba, SP, Brazil

\begin{abstract}
The purpose of this study was to assess the in vitro the antimicrobial efficacy of chlorhexidine gluconate gel as an endodontic auxiliary chemical substance compared to sodium hypochlorite $(\mathrm{NaOCl})$ and chlorhexidine gluconate solution. The antimicrobial efficacy of the tested substances was evaluated using the agar diffusion test. The growth inhibition zones produced by $0.2 \%, 1 \%$ and $2 \%$ chlorhexidine gel were evaluated against 5 facultative anaerobic bacteria and 4 pigmented Gram-negative anaerobes, and compared to the results obtained by $\mathrm{NaOCl}$ and chlorhexidine solution. The largest growth inhibition zones were produced when the test bacteria were in contact with $2 \%$ chlorhexidine gluconate gel $(11.79 \mathrm{~mm})$, being significantly different $(\mathrm{p}<0.05)$ from the growth inhibition zones produced by all NaOClconcentrations, including 5.25\% $(9.54 \mathrm{~mm})$. However, there was no statistically significant difference $(\mathrm{p}>0.05)$ between the growth inhibition zones obtained with equal concentrations of chlorhexidine solution and gel. The results of this study indicate that, as far as its antimicrobial properties are concerned, chlorhexidine gel has a great potential to be used as an endodontic auxiliary chemical substance.
\end{abstract}

Key Words: chlorhexidine gel, endodontics, antimicrobial activity, irrigants.

\section{INTRODUCTION}

Microbial control by biomechanical methods is very important to the effectiveness of the endodontic therapy (1). Anaerobic bacteria, mainly black-pigmented Gram-negative, have been related to the signs and symptoms of endodontic disease, but facultative bacteria, such as Enterococcus faecalis, have also been isolated from pathologically involved root canals, and may be involved in failure of endodontic therapy (2).

Root canals with complex anatomy limit the mechanical action of endodontic instruments and thus it is highly recommendable the use of chemical solutions with antimicrobial activity, ability to dissolve organic tissues, lubricant properties and low cytotoxicity as an adjunct to the mechanical preparation (3).
Sodium hypochlorite $(\mathrm{NaOCl})$ has been widely used as the endodontic irrigant of choice, although alternative solutions have already been studied. The use of chlorhexidine gluconate as an irrigant during root canal therapy has been suggested based on its antibacterial effect, substantivity and less malodor and cytotoxicity than $\mathrm{NaOCl}(4)$.

Much attention has been directed towards the chemical properties of endodontic irrigants, but there has not been much research on improving their mechanical abilities. The substances used to irrigate the root canal system are most frequently solutions. The use of viscous irrigants, such as glycerin-based chlorhexidine gluconate or urea peroxide has been suggested demonstrating an exceptional lubricant action and improved antimicrobial properties (5). Nevertheless,

Correspondence: Prof. Dr. Caio C. R. Ferraz, Faculdade de Odontologia de Piracicaba, Área Endodontia, UNICAMP, Caixa Postal 52, 13414-018 Piracicaba, SP, Brasil. Tel +55-19-2106-5215. Fax +55-19-2106-5218. e-mail: cferraz@fop.unicamp.br 
the viscous bases used in these irrigants have little solubility in water, leaving residues on the dentinal walls that interfere with the adequate filling of the root canal system (6). Natrosol gel, however, is a highly efficient, inert, hydrosoluble, non-ionic thickening agent based on anionic substances, such as the chlorhexidine gluconate, which is largely used to thicken shampoos, gels and soaps. Chlorhexidine in natrosol base has already proved its excellent mechanical ability as an intracanal irrigant for smear layer removal (7).

The use of chlorhexidine gel as an endodontic irrigant has been recently proposed (7), which justifies the small number of studies comparing its antimicrobial activity to that of commonly used endodontic irrigants. Therefore, the purpose of this study was to assess in vitro the antimicrobial efficacy of chlorhexidine gluconate based on natrosol gel compared to $\mathrm{NaOCl}$ and chlorhexidine solution.

\section{MATERIAL AND METHODS}

The microbial species used in this study were 5 facultative anaerobic bacteria and 4 pigmented Gramnegative anaerobes commonly isolated from infected root canals, as follows: Staphylococcus aureus (ATCC 25923), Enterococcus faecalis (ATCC 29212), Streptococcus sanguis (ATCC 10556), S. sobrinus 6715, Actinomyces naeslundii M104, Porphyromonas gingivalis, P. endodontalis, Prevotella intermedia and Prevotella denticola. The last four microorganisms were clinical isolates. The facultative anaerobes were kindly donated by the Center of Oral Biology of the University of Rochester, NY, USA.

Each microbial strain was evaluated against the following irrigants: chlorhexidine gluconate gel $(0.2 \%$, $1 \%$ and $2 \%$; chlorhexidine gluconate solution $(0.2 \%$, $1 \%$ and $2 \%)$; and $\mathrm{NaOCl}(0.5 \%, 1 \%, 2.5 \%, 4 \%$ and $5.25 \%$ ). All substances were prepared by the same manufacturer (Endogel; Essencial Frama Ltd., Itapetininga, SP, Brazil). Saline was used as a control.

All microorganisms were previously subcultured onto appropriate culture media and under gaseous conditions. The facultative strains were individually inoculated into tubes containing $5 \mathrm{~mL}$ of sterile $0.85 \%$ saline suspension, adjusted to a concentration of 0.5 of the McFarland BaSO4 standard $\left(1.5 \times 10^{8}\right.$ colonyforming units). An amount of $500 \mu \mathrm{L}$ of each test microbial suspension were inoculated into glass flasks containing $50 \mathrm{~mL}$ of Brain Heart Infusion (BHI) agar at $46^{\circ} \mathrm{C}$, vortexed and poured onto $130 \mathrm{~mm}$-plates containing solidified layer of Mueller Hinton (MH) agar. For the anaerobes, sterile swabs were dipped into the

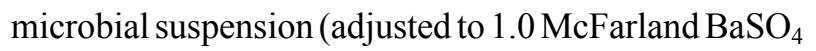
standard $=3.0 \times 10^{8}$ colony-forming units) and inoculated onto pre-reduced $70 \mathrm{~mm}$-plates containing $5 \%$ sheepblood-Fastidious Anaerobe Agar. The inoculum procedures were appropriate to provide a semi-confluent growth of the tested microorganisms.

Stainless steel tubes $(8.0 \times 1.0 \times 10 \mathrm{~mm}$; inner diameter $=6 \mathrm{~mm}$ ) were placed onto the media surface and fulfilled with $40 \mu \mathrm{L}$ of each test substance, followed by incubation at $37^{\circ} \mathrm{C}$ in appropriate gaseous and time conditions (i.e., facultatives: $48 \mathrm{~h}$ at a $\mathrm{CO}_{2}$ incubator, and anaerobes: 7 days in an anaerobic work station). After the incubation period, the growth inhibition zone was considered as the shortest distance $(\mathrm{mm})$ from the outside margin of the cylinder to the initial point of the microbial growth. Kruskal-Wallis statistical test was used to evaluate the differences between the susceptibility of individual microbial species to the endodontic irrigants. Significance level was set at 5\%.

\section{RESULTS}

The mean zones of microbial growth inhibition produced by the different concentrations of chlorhexidine gel/solution and $\mathrm{NaOCl}$ are presented in Tables 1 and 2, respectively. Figure 1 shows graphically the mean zones of microbial growth inhibition created by the

Table 1. Mean zones of microbial growth inhibition (diameter, in $\mathrm{mm}$ ) produced by the different concentrations of chlorhexidine solution and gel.

\begin{tabular}{lrrrrrr}
\hline \multirow{2}{*}{$\begin{array}{l}\text { Microbial } \\
\text { strains }\end{array}$} & $\begin{array}{c}\text { CLX-S } \\
\text { CLX-S }\end{array}$ & \multicolumn{2}{c}{ CLX-S CLX-G } & CLX-G & CLX-G \\
& $0.2 \%$ & $1 \%$ & $2 \%$ & $0.2 \%$ & $1 \%$ & $2 \%$ \\
\hline S.aureus & 4.00 & 8.67 & 8.67 & 6.67 & 9.33 & 9.67 \\
E.faecalis & 4.00 & 4.67 & 5.00 & 3.17 & 3.50 & 4.33 \\
S. sanguis & 6.00 & 8.67 & 9.33 & 6.33 & 8.00 & 8.33 \\
S. sobrinus & 9.00 & 9.00 & 10.33 & 6.33 & 10.00 & 10.33 \\
A.naeslundii & 5.83 & 8.67 & 8.67 & 5.17 & 6.00 & 6.67 \\
P.gingivalis & 11.17 & 16.50 & 17.00 & 14.00 & 17.83 & 20.33 \\
P.endodontalis & 10.00 & 12.67 & 15.67 & 11.00 & 13.67 & 17.83 \\
P.intermedia & 12.33 & 13.33 & 17.33 & 16.17 & 20.00 & 21.33 \\
P.denticola & 5.50 & 6.50 & 7.00 & 4.17 & 6.00 & 7.30 \\
\hline
\end{tabular}


tested irrigants.

All tested microorganisms were affected by the different concentrations of chlorhexidine gluconate, either in the solution or gel form. Similar results were not observed for $\mathrm{NaOCl}$, especially in low concentrations.

The largest growth inhibition zones were produced when the tested bacteria were in contact with $2 \%$ chlorhexidine gluconate gel $(11.79 \mathrm{~mm})$, being significantly different $(\mathrm{p}<0.05)$ from the growth inhibition zones produced by all $\mathrm{NaOClconcentrations,} \mathrm{including}$ $5.25 \%(9.54 \mathrm{~mm})$.

There was no statistically significant difference $(p>0.05)$ between the growth inhibition zones obtained with equal concentrations of chlorhexidine solution and gel, though the gel form produced zones with larger diameters than the solution.

\section{DISCUSSION}

$\mathrm{NaOCl}$ is widely used in endodontics as a root canal irrigant at different concentrations. Laboratorial and clinical investigations have shown that $\mathrm{NaOCl}$ produces an effective chemomechanical debridement of the root canal system, due to its properties, such as lubricanting action for instrumentation, antimicrobial activity and dissolution of pulp tissue (8).

Exactly how $\mathrm{NaOCl}$ destroys microorganisms has never been demonstrated experimentally. The dissociation of hypocholrous acid is dependent on the $\mathrm{pH}$ and maintenance of the equilibrium between $\mathrm{HOCl}$ and $\mathrm{OCl}^{-}$, even though $\mathrm{HOCl}$ is constantly consumed by its germicidal function (9). However, some microor-

Table 2. Mean zones of microbial growth inhibition (diameter, in $\mathrm{mm}$ ) produced by the different concentrations of $\mathrm{NaOCl}$.

\begin{tabular}{lccccc}
\hline $\begin{array}{l}\text { Microbial } \\
\text { strains }\end{array}$ & $\begin{array}{c}\mathrm{NaOCl} \\
0.5 \%\end{array}$ & $\begin{array}{c}\mathrm{NaOCl} \\
1 \%\end{array}$ & $\begin{array}{c}\mathrm{NaOCl} \\
2.5 \%\end{array}$ & $\begin{array}{c}\mathrm{NaOCl} \\
4 \%\end{array}$ & $\begin{array}{c}\mathrm{NaOCl} \\
5.25 \%\end{array}$ \\
\hline S. aureus & 4.33 & 4.67 & 4.83 & 4.83 & 5.83 \\
E.faecalis & 0.00 & 0.00 & 1.50 & 2.17 & 3.17 \\
S. sanguis & 0.33 & 0.67 & 2.67 & 2.00 & 3.00 \\
S. sobrinus & 0.00 & 0.00 & 1.83 & 2.83 & 3.50 \\
A.naeslundii & 0.00 & 0.00 & 1.83 & 6.67 & 8.67 \\
P. gingivalis & 7.67 & 11.67 & 17.83 & 19.67 & 22.83 \\
P.endodontalis & 0.00 & 2.83 & 4.17 & 6.00 & 11.50 \\
P. intermedia & 0.00 & 10.33 & 11.33 & 12.83 & 24.50 \\
P. denticola & 0.00 & 1.33 & 2.00 & 2.33 & 2.83 \\
\hline
\end{tabular}

ganisms are resistant to $\mathrm{NaOCl}$, especially at low concentration (10), which was also demonstrated in this study. On the other hand, the usage of $\mathrm{NaOCl}$ in high concentrations is undesirable because it is irritating to the periapical tissues (9). Therefore, several attempts have been made in order to find other efficient irrigants that provide a high antimicrobial action with low toxicity.

Chlorhexidine gluconate is a cationic bisguanide that seems to act by adsorption onto the cell wall of the microorganism and causing leakage of intracellular components. At low concentrations, chlorhexidine has a bacteriostatic effect, causing the leaching of small molecular weight substances from microorganisms. At higher concentrations, chlorhexidine has a bactericidal effect due to cytoplasmic precipitation and/or coagulation, probably caused by protein cross-linking (11). The present work not only confirmed the efficiency of chlorhexidine as an antimicrobial agent against oral microorganisms, as reported elesewhere $(12,13)$, but also demonstrated bacterial susceptibility (even resistant organisms) to chlorhexidine gel at both tested concentrations $(0.2 \%$ and $2 \%)$.

In the present study, a modified agar diffusion test was used, which has been widely employed to assess the antimicrobial activity of several endodontic materials in vitro (14). The in vitro susceptibility of 9 bacterial species was tested against 3 concentrations of $\mathrm{NaOCl}(0.5 \% ; 1 \% ; 2.5 \% ; 4 \% ; 5.25 \%)$ and 3 concentrations of chlorhexidine gluconate gel or solution $(0.2 \%, 1 \%$ and $2 \%)$. Differences in the bacterial vulner-

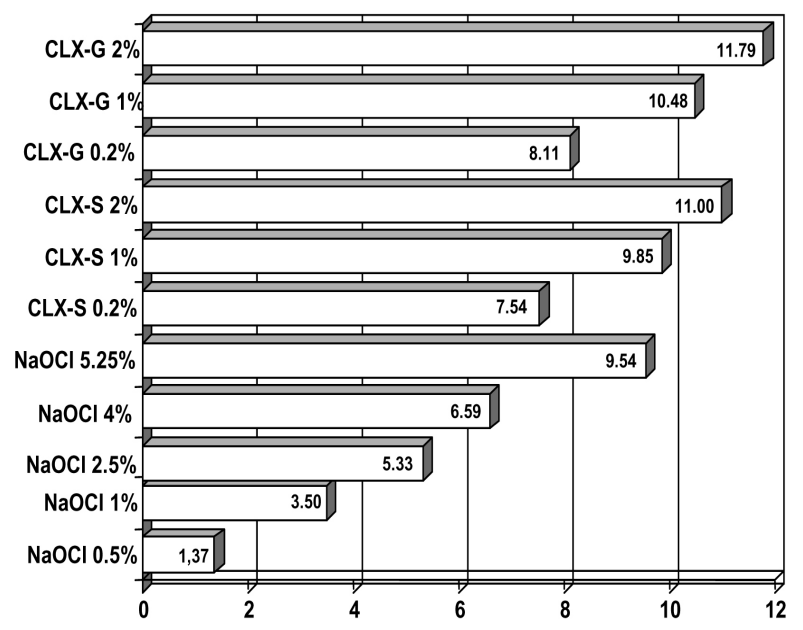

Figure 1. Graphic presentation of the mean zones of microbial growth inhibition (in $\mathrm{mm}$ ) created by the tested irrigants. CLX$\mathrm{G}=$ Chlorhexidine gluconate gel; $\mathrm{CLX}-\mathrm{S}=$ Chlorhexidine gluconate solution; $\mathrm{NaOCl}=$ Sodium hypochlorite. 
ability to the biomechanical procedures during the endodontic treatment have been identified (15). The present results also indicated great variations in the chemical susceptibilities of the tested microorganisms.

$\mathrm{NaOCl}$ has an organic tissue dissolving property that is desirable during its action into contaminated root canals, removing pulp remnants that frequently remain after the mechanical preparation. Nevertheless, this dissolving ability is not selective, which means that if $\mathrm{NaOCl}$ reaches the periapical region there may be tissue damage.

The toxic effects of $\mathrm{NaOCl}$ have been evaluated (16). The authors concluded that $0.025 \%$ is a safe concentration of $\mathrm{NaOCl}$ to clinical use, maintaining the antimicrobial action without harmful effects to the periapical tissues. Nevertheless, the results of the present study and others $(8,10)$ indicate that $\mathrm{NaOCl}$, mainly at low concentrations, has little or no effect against some microorganisms, such as E. faecalis, $S$. sanguis, $S$. sobrinus, and even fastidious bacteria, such as $P$. denticola. The present results showed that $5.25 \%$ was the most efficient concentration of $\mathrm{NaOCl}$, which is consistent with the findings of a previous work (17).

Despite the large use of several concentrations of $\mathrm{NaOCl}$ as endodontic irrigants, other substances with less cytotoxicity and larger antimicrobial spectrum should be studied. Chlorhexidine gluconate has been used in Endodontics as an irrigating solution, but most frequently in a solution presentation. Ferraz et al. (7) assessed the mechanical action of chlorhexidine gel as an endodontic irrigant, demonstrating its ability to remove smear layer and capacity to eliminate $E$. faecalis from infected root canals in vitro. Chlorhexidine gel has also been evaluated as an intracanal medication, with a good performance (14). Natrosol gel, used as a base to the chlorhexidine gluconate in the present study, is a greatly efficient inert, water-soluble thickening agent, which is largely used to thicken shampoos, gels and soaps. The antimicrobial activity observed in the agar diffusion test revealed that the chlorhexidine gel produced larger zones of microbial growth inhibition than the solution with equal concentrations, but no statistically significant difference was confirmed. On the other hand, the growth inhibition zones promoted by both presentation forms of $2 \%$ chlorhexidine were significantly larger than those created by all $\mathrm{NaOCl}$ concentrations, including $5.25 \%$. All microbial species tested here were sensitive to chlorhexidine gluconate, either in gel or in solution, in all tested concentrations. Chlorhexidine demonstrated antimicrobial action with a broad spectrum, in agreement with the results of a previous study (12).

The lowest concentration of chlorhexidine gluconate evaluated in the present study $(0.2 \%)$ showed an in vitro antimicrobial activity equivalent to that of $5.25 \% \mathrm{NaOCl}$, in agreement with which has been reported elsewhere (18). Delany et al. (12) studied the $0.2 \%$ chlorhexidine gluconate solution in extracted teeth, suggesting that this concentration could be used efficiently as either an irrigant solution or an intracanal medication.

The results of the present study confirmed those of Ohara et al. (19), though those authors tested only chlorhexidine solution. In both experiments, chlorhexidine gluconate was superior to $\mathrm{NaOCl}$ against various microorganisms in distinct in vitro experimental models. One of the parameters evaluated by Ohara et al. (19) was the contact time required by each solution to eliminate pathogens that are frequently isolated from infected root canals. Chlorhexidine gluconate was the most efficient substance, with better results than $5.25 \% \mathrm{NaOCl}$.

On the other hand, Gomes et al. (20) verified that $2 \%$ chlorhexidine solution and $5.25 \% \mathrm{NaOCl}$ had similar antimicrobial performance, taking less than $30 \mathrm{~s}$ to eliminate E. faecalis. The authors also reported that $2 \%$ chlorhexidine gel took $1 \mathrm{~min}$ to kill the same bacterial strain. However, all irrigants proved to have potential to fulfill contact time necessary under clinical conditions because, during endodontic treatment, bacteria are in contact with irrigants for around 30 to $60 \mathrm{~min}$ (17).

Based on the antimicrobial efficacy observed in the present study allied to the excellent performance demonstrated in previous investigations $(7,20)$, it may be concluded that chlorhexidine gel has a great potential to be used as an intracanal auxiliary chemical substance.

\section{RESUMO}

O objetivo deste estudo foi avaliar in vitro a atividade antimicrobiana do gluconato de clorexidina gel, como irrigante endodôntico, comparando-o ao hipoclorito de sódio $(\mathrm{NaOCl})$ e ao gluconato de clorexidina líquido. A atividade antimicrobiana das substâncias testadas foi avaliada pelo teste de difusão em ágar. As zonas de inibição de crescimento bacteriano produzidas pela clorexidina gel a $0,2 \% ; 1 \%$ e $2 \%$ foram observados frente a 5 espécies de bactérias anaeróbias facultativas e 4 espécies de anaeróbios estritos, Gram-negativos e produtores de pigmento negro; e comparados com os resultados obtidos pelo $\mathrm{NaOCl}$ e 
pela clorexidina líquida. As maiores zonas de inibição foram produzidas quando as bactérias testadas ficaram em contato com a clorexidina a $2 \%$ em gel $(11,79 \mathrm{~mm})$, apresentando diferença estatisticamente significante $(\mathrm{p}<0,05)$ quando comparados às zonas de inibição de crescimento bacteriano produzidas por todas as concentrações avaliadas de $\mathrm{NaOCl}$, incluindo $5,25 \%$ $(9,54 \mathrm{~mm})$. No entanto, não houve diferença estatisticamente significante $(p>0,05)$ comparando as zonas produzidas por concentrações equivalentes de clorexidina líquida ou gel. Os resultados indicaram que a clorexidina em gel tem grande potencial para ser usada como substância química auxiliar quanto às suas propriedades antimicrobianas.

\section{REFERENCES}

1. Kakehashi S, Stanley HR, Fitzgerald RJ. The effects of surgical exposures of dental pulps in germ-free and conventional laboratory rats. Oral Surg Oral Med Oral Pathol 1965;20:340349.

2. Gomes BPFA, Drucker DB, Lilley JD. Association of endodontic symptoms and signs with particular combinations of specific bacteria. Int Endod J 1996;29:69-75.

3. Safavi KE, Spangberg LSW, Langeland K. Root canal dentine tubule disinfection. J Endod 1990;16:207-210.

4. Dametto FR, Ferraz CC, de Almeida Gomes BP, Zaia AA, Teixeira FB, de Souza-Filho FJ. In vitro assessment of the immediate and prolonged antimicrobial action of chlorhexidine gel as an endodontic irrigant against Enterococcus faecalis. Oral Surg Oral Med Oral Pathol Oral Radiol Endod 2005;99:768-772.

5. Tucker JW, Mizrahi S, Seltzer S. Scanning electron microscopic study of the efficacy of various irrigation solutions: urea, Tubulicid Red, and Tubulicid Blue. J Endod 1976;2:7178 .

6. Camps J, Macouin G. RC Prep and immediate endodontic obturation. Inf Dent 1990;72:4095-4099.

7. Ferraz CCR, Gomes BPFA, Zaia AA, Teixeira FB, SouzaFilho FJ. In vitro assessment of the antimicrobial action and mechanical ability of chlorhexidine gel as an endodontic irrigant. J Endod 2001;27:452-455.

8. Abou-Rass M, Piccinino MV. The effectiveness of four clinical irrigation methods on the removal of root canal debris. Oral Surg Oral Med Oral Pathol 1982;54:323-328.
9. Spangberg L, Egstrom B, Langeland K. Biologic effects of dental materials. 3. Toxicity and antimicrobial effect of endodontic antiseptics in vitro. Oral Surg Oral Med Oral Pathol 1973;36:856-871.

10. Baumgartner JC, Cuenin PR. Efficacy of several concentrations of sodium hypochlorite for root canal irrigation. J Endod 1992;18:606-612.

11. Fardal O, Turnbull RS. A review of the literature on use of chlorhexidine in dentistry. $J$ Am Dent Assoc 1986;112:863869.

12. Delany GM, Patterson SS, Miller CH, Newton CW. The effect of chlorhexidine gluconate irrigation on the canal flora of freshly extracted necrotic teeth. Oral Surg Oral Med Oral Pathol 1982;53:518-522.

13. Wang CS, Arnold RR, Trope M, Teixeira FB. Clinical efficiency of $2 \%$ chlorhexidine gel in reducing intracanal bacteria. J Endod 2007;33:1283-1289.

14. Siqueira Jr JF, Uzeda M. Intracanal medicaments: evaluation of the antibacterial effects of chlorhexidine, metronidazole, and calcium hydroxide associated with three vehicles. J Endod 1997;23:716-719.

15. Gomes BPFA, Lilley JD, Drucker DB. Variations in the susceptibilities of components of the endodontic microflora to biomechanical procedures. Int Endod J 1996;29:235-241.

16. Heggers JP, Sazy AJ, Stenberg BD, Strok LL, McCauley RL, Hernos DN, Robson MC. Bacterial and wound-healing properties of sodium hypochlorite solutions. The 1991 Linderberg Award. J Burn Care Rehabil 1991;12:420-424.

17. Yesilsoy C, Whitaker E, Cleveland D, Phillips E, Trope M. Antimicrobial and toxic effects of established and potential root canal irrigants. J Endod 1995;10:513-515.

18. Jeansonne MJ, White RR. A comparison of $2.0 \%$ chlorhexidine gluconate and $5.25 \%$ sodium hypochlorite as antimicrobial endodontic irrigants. J Endod 1994;20:276278.

19. Ohara PK, Torabinejad M, Kettering JD. Antibacterial effects of various endodontic irrigants on selected anaerobic bacteria. Endod Dent Traumatol 1993;9:95-100.

20. Gomes BPFA, Ferraz CCR, Vianna ME, Berber VB, Teixeira FB, Souza-Filho FJ. In vitro antimicrobial activity of several concentrations of sodium hypochlorite and chlorhexidine gluconate in the elimination of Enterococcus faecalis. Int Endod J 2001;34:424-428. 